\title{
The Feminist Writing of CharlotTe Perkins Gilman: PAUSING FOR THE CHRONOTOPE
}

\author{
Carolina Núñez Puente \\ Universidad de la Coruña
}

\begin{abstract}
RESUMEN
El propósito de este artículo es al menos triple. En primer lugar, espera mostrar un diálogo fructifero entre las perspectivas críticas feminista y bajtiniana. Segundo, mediante una lectura cronotópica de la saga de C. P. Gilman, Herland-Ourland (1915-6), el artículo explora que Gilman tuvo que transformar ciertos cronotopos bajtinianos (e.g. el cronotopo del idilio, el cronotopo del castillo), como también que inventar otros (e.g. el cronotopo de la violación, el cronotopo de la maternidad), para desarrollar una crítica feminista-dialógica de la sociedad de su tiempo. Tercero, el artículo trata las diferentes perspectivas entre las feministas de la 'primera ola,' como Gilman, y las feministas de la 'tercera ola' actual. Por último, se espera que los/as lectores/as que hagan una lectura crítica de Bakhtin y Gilman aprendan acerca de las características dialógicas de las relaciones auténticamente intersubjetivas/éticas entre las personas.
\end{abstract}

Palabras clave: feminismo, novela, cronotopo, género (femenino), sociología.

\section{ABSTRACT}

The purpose of this paper is at least triple-fold. First of all, it hopes to show a fruitful dialogue between feminist and Bakbtinian critical approaches. Second, by means of a chronotopic reading of C. P. Gilman's saga, Herland-Ourland (1915-6), the paper explores that Gilman had to transform certain Bakbtinian chronotopes (e.g. the chronotope of idyll, the castle chronotope), and also to invent new ones (e.g. the chronotope of rape, the motherbood chronotope), in order to develop a feminist-dialogic critique of the society of her time. Third, the paper touches upon the different points-of-view between 'first-wave' feminists like Gilman and the feminists of the ongoing 'third wave.' Finally, it is expected that readers, who perform a critical reading of Bakbtin and Gilman, learn about the dialogical features of truly intersubjective/ethical relations between people.

Keywords: feminism, novel, chronotope, gender, sociology. 
Between the years 1915 and 1916, Charlotte Perkins Gilman serialized Herland and its Sequel, With Her in Ourland in her own periodical, The Forerunner. In 1979, Herland was reedited in one volume subtitled "A Lost Feminist Utopian Novel." One is inclined to affirm that, very probably, Gilman would disagree with the word 'novel' in this subtitle, given her opinion that she did not write that kind of "literature." In spite of Gilman's disagreement, this article is intended to mainly evaluate the feminist and novel-like qualities of the Herland-Ourland saga. To do so, I have chosen to read Gilman's text through the chronotope, a critical tool to approach the novel developed by the Russian thinker Mikhail M. Bakhtin. ${ }^{2}$

In "Forms of Time and of the Chronotope," Bakhtin defined the chronotope as an "organizing cente[r] for the fundamental narrative events [,] ... where the knots of the narrative are tied and untied ... [T] [it] belongs the meaning that shapes the narrative" (1937-8: 250). Since chronotopes are also "the basis for distinguishing generic types" (250-1), Bakhtin associated a specific genre with a specific chronotope, e.g.: the Gothic with the 'castle chronotope,' realism with the 'parlor-salon chronotope.' It is vital to acknowledge that chronotopes change over time, hence the subtitle of the essay, "Notes toward a Historical Poetics." If for the Bakhtin's Circle "genres are neither sets of rules nor accumulations of forms and themes" but forms of thinking that allow the reader to view the world in a specific way (Morson \& Emerson 1997: 185), then they are form-shaping

\footnotetext{
${ }^{1}$ In the closing article of The Forerunner, Gilman explained that "[ $t$ ]he subject matter [of my periodical] ... is not to be regarded as 'literature,' but as an attempt to set forth certain views of life which seemed to the author of real importance to human welfare" ("Summary" 1916: 286). In other writings, Gilman criticized the fact that literature was being turned into a "'business" (1890: 105) and that her "[s]ocial philosophy" might have represented/sold little in such a market (1935: 303-4).

${ }^{2}$ Bakhtin has been proclaimed the greatest disseminator of "dialogics." It would be absurd (not to say anti-dialogical) to define/confine the term dialogics, which changes meaning throughout Bakhtin's own oeuvre, as well as through the Bakhtinians' interpretations. As obvious as it seems, "dialogics" comes from "dialogue" and points out a relation between languages-(con)texts; an interaction between author and reader, speaker and listener. In this article, I call "dialogic/al" the (fictional) people and texts that strive for dialogue in an inter-subjective manner. Of course, so that a dialogue is really dialogical, all parties must have equivalent participative rights to it. Considering the current social sphere-the continuing racism, sexism, and so on-, one can deduce the difficulties involved in the existence of dialogical conditions, a deduction that reveals the utopian character of Bakhtin's thought.
} 
ideologies. In the light of this, if masculinist chronotopes are reproduced throughout literary history, they contribute to the perpetuation of patriarchy. Throughout this article, I explain why Gilman, a feminist thinker, had to parody some chronotopes as well as to invent feminist ones in order to deal with some of the problematics of gender-such as 'gender violence' and the need for a 'social(ized conception of) motherhood.' Bakhtin never wrote about women writers or discussed chronotopes protagonized by female characters, something I try to offset here. ${ }^{3}$ Throughout my reading of Gilman's saga, I interpret the feminist (re)writing/gendering of a series of chronotopes, which had not been gendered by Bakhtin-the chronotope of the road, the idyll chronotope and the castle chronotope, to name a few-, and the feminist creation of 'new' chronotopes unthought of by Bakhtin-such as the chronotope of estrangement, the chronotope of real(istic) love and the chronotope of rape, among others. Furthermore, paraphrasing Gary Saul Morson (1991), Bakhtin's literary hero was not simply the novel but the realist novel. Throughout this article, I also show why Gilman had to alter realism and add elements of utopia to her novel in order to continue to develop her feminist critique. One must not forget that Gilman was a first-wave feminist and a sociologist with deep interests in the didactic effects of her writings-see Gilman: 1913. Bakhtin and his Circle had deep interests in the soci(ologic)al aspects of literature too, hence their theorization of a Sociological Poetics (Medvedev \& Bakhtin: 1978).

Importantly for feminists, Bakhtin argued over the "continual renew[al] of the work [of art] through the creative perception of ... readers" (1937-8: 254). That is, future readers will be able to detect (and gender) chronotopes that were unimaginable to its contemporaries. Given my existence as a reader in a different time-space/chrono-tope to that of Bakhtin, a chronotope currently known as the third wave of feminism, I would like to introduce a 'new' idea by which the chronotope is a metaphorical 'pause' within dialogics. That is, from a feminist dialogical perspective, gendered chronotopes can provide writer and reader with a metaphorical 'pause' that involves a feminist critique of his-her own society. The hope is that the 'pause' in question can be the first step to end the construction of hierarchies between men and women. The idea of the

\footnotetext{
${ }^{3}$ Lynne Pearce has expressed suspicion of the notion of chronotope as "gender neutral" (1994: 119). Her critique belongs to a school of feminism named 'feminist dialogics' by Pearce herself. Among the feminists who reread, challenge and expand upon Bakhtin's writings are: Bauer: 1988, Bauer \& McKinstry: 1991, Hohne \& Wussow: 1994, Herrmann: 1989, Howard: 1994, Little: 1996, Yaeger: 1988, and, leaving modesty aside, myself too.
} 
chronotope as providing a feminist reading 'pause' is applied in my close reading of Gilman's two-part novel, in which I 'pause' to rethink women's problems.

I will begin my chronotopic reading with an overview of Gilman's characters, who can create their own chronotopes, as the rogue, the clown and the fool did for Bakhtin (1937-8: 159). ${ }^{4}$ Already in the early twentieth century, Gilman protested: "No wonder [woman] has no place in art-she has had no existence before. Women as persons, human beings [...] are quite new to us" ("Coming" 1915: 124). Still in the late twentieth century, Joanna Russ has asserted that fantastic texts allow authors to write stories that are not "about men qua Man and women qua Woman" (1995: 91). According to Russ, the fantastic is the only genre where one may represent "Woman as Intellectual" (83), which is to say, as a subject. In Gilman's utopian/fantastic novel, the three female protagonists (Ellador, Celis and Alima) are "foresters" (Herland 1915: 124), a profession usually associated with physical strength. Furthermore, the Herlanders' intellectual abilities are praised throughout: their "genius [...] subtle understanding" (28), their "freshness of mind [... and] intellectual power" (Ourland 1916: 62). The so-called 'masculine' features characterizing these three female personalities are part of the process of deconstructing the idea of "woman." More specifically, in the early twentieth century, each Herlander might stand for a chronotope of the New Woman, who was "antithetical to the Victorian stereotype of the proper lady and the angel in the house" (Miller 1994: 14). For third-wave feminist readers, the problem is that all Herlanders represent the same (New) woman or a woman that is white, middle-class, heterosexual, educated, and so on. This reveals that the concept of the New Woman was biased and that Gilman gave no protagonism to the women that were not included in it. I will come back to this question.

According to Elaine Showalter (1988), the male characters created by the novelists of the "Feminine Period" follow a tradition of binary oppositions

\footnotetext{
${ }^{4}$ In an introductory note to Ourland, the second part of the saga, Gilman provided the following "Synopsis" of Herland, the first part: "Three American young men discover a country inhabited solely by women, who were Parthenogenetic, and had borne only girl children for two thousand years; they marry three of the women. Two of the men and one woman leave the country of Herland to return to America; Jeff Margrave remaining with his wife, Celis, a willing citizen; Terry O. Nicholson being expelled for bad conduct; and Ellador electing to go with her husband, Vandyck Jennings" (Ourland 1916: 61). Ourland deals with Mr. and Mrs. Jennings' visit to several places in Europe, Asia and America, which are 'lands' of 'our' known world (Ourland). As expected, the people of Herland are called 'Herlanders' and, those of Ourland, 'Ourlanders.'
} 
similar to the one applied by male writers onto female characters. Thus, Showalter has contended, in the earliest tradition of women writers, 'meek' and 'brute' male characters proliferated mainly as the clergyman- and Rochestertypes (143). Of the three male protagonists of Herland, Jeff Mar(-)grave is a serious man, who can represent the 'meek,' and Terry O. Nicholson certainly is the most 'terrestrial' or 'brute' of the three. In addition to these two, Gilman created a third intermediate character, Vandyck Jennings, whom I have decided to call the 'dialogic man,' and who may stand for a new chronotope. Gilman's break with the hierarchical model of representation indicates a literary ability to go beyond established parameters. Van is the most dialogical character of the saga, not only because of his ability to talk and listen, but also due to his openness to change (Bakhtin 1941: 10, 34). Though open-minded, at the beginning of the saga Van has deep-rooted patriarchal ideas: "this is a civilized country! [...] There must be men" (Herland 1915: 11). ${ }^{5}$ After his stay in Herland and through his relationship with Ellador, Van progressively changes his mind especially with respect to women.

It is not at all surprising that Gilman, who has been identified as a radical feminist (Humm 1999: 111), would write a utopian novel. In Herland, there is no need to travel very far in space (such as to another planet) or in time (such as to the future). Herland is situated in some hidden place of the Earth, some have suggested in South America-e.g. Annas: 1981, Peyser: 1998-, and in a time contemporaneous with that of its first readers'. Surprisingly though, the inhabitants of this land descend from an "Aryan stock" (Herland 1915: 54), which corroborates Gilman's exclusive concern with white people. According to Annie Cranny-Francis, one of the conventions of utopian fiction is "estrangement," or setting the story in another time and place (1990: 110), so that the reader "is posited to see her/his own society from a different perspective" (emphasis mine). Cranny-Francis has commented that "estrangement" has been used by feminists, "[s]o readers and writers are freed from the restrictions of a realist reading, which tends to restrict representation to an imitation" (193). This liberatory impulse is consistent with Gilman's wish to alter realist norms, which she practised throughout her oeuvre, the most famous being her "Yellow Wallpaper." Following Cranny-Francis and bringing together the 'chrono-topic'

${ }^{5}$ In Herland-Ourland, there is an obsessively recurrent binary opposition between 'civilized' and 'savage' (Herland 1915: 26, 29, 52, 87, 135; Ourland 1916: 75, 95-96, 99, 103, 178). As expected from a text of the so-called fin-de-siècle, being 'civilized' here means being educated in the best Eurocentric and patriarchal fashion. 
origin of 'u-topia' and its intrinsic characteristic of estrangement, I would suggest that a feminist utopian saga such as Herland-Ourland creates a gendered 'chronotope of estrangement' in order "to construct a feminist reading position as a strategy in the production of a feminist subject" (Cranny-Francis 1990: 125)-thus the "creative chronotope" that occurs between author and reader (Bakhtin 1937-8: 254).

In order to further criticize the literary establishment, Gilman started by refusing to "follo[w] masculine canons" avant la lettre ("Masculine" 1911: 122), which she summarized in "two main branches ... the Story of Adventure, and the Love Story" (119). Both 'adventure' and 'romance' can be conventions of the utopian genre (Cranny-Francis 1990: 200, Donaldson 1989: 376, Ferns 1998: 24) and Gilman rewrote these two fictional forms in Herland. Aleta Cane has read the first part of the saga as a feminist response to the male quest romance. More concretely, Susan S. Gubar (1983) has pointed out Herland is a rewriting of H. Rider Haggard's She. Herland starts with three men (Van, Jeff and Terry), who decide to explore a mythical "Woman Land" (Herland 1915: 2), which has "a strictly Amazonian nature" (5). Contrary to their dreams of colonization, 'explorers' are 'explored,' 'masters' are 'taught,' and 'conquerors' are 'conquered'-Van by Ellador, Jeff by Celis, Terry by Alima. Through the undoing of the conventions of imperialist narratives, Gilman revealed that male authors have always been "monopolizing this form of art [literature] with special favor ... [so] they have given the world a masculinized literature" ("Masculine" 1911: 116), that is, written by and for men. In Herland, the narrator emphasizes that the story is not about the men's "expedition" (2) and insists in chapter V, purposefully entitled "A Unique History:" "It is no use for me to try to piece out this account with adventures. If the people who read it are not interested in these amazing women and their history, they will not be interested at all" (49). ${ }^{6}$ That is, the narration forces readers to 'pause' and question their prejudice before continuing their reading. If they continue, readers will learn to see women differently, as corresponds to the kind of first-wave feminist writing (Lane: 1979). Given the saga's gendering of the masculinist "Story of Adventure," the greatest adventure here is meeting the women themselves-an adventure Ellador and Van continue in Ourland. In fact, the whole saga can be read through the 'chronotope of adventure,' meaning the adventure of getting to know the other

6 Apart from being the male protagonist, Vandyck becomes Herland-Ourland's extradiegetic homodiegetic narrator-for clarification of this terminology, see Genette: 1990. 
through the 'roads' of dialogue. This explains why a dialogue format is used in most chapters.

As Bakhtin contended, the "major chronotope" of adventure-time is "the road" (1937-8: 120), hence "the important role of the road in the history of the novel" (244). ' Bakhtin further elaborated that, when the 'road' and the 'encounter chronotope' appear together, the combination is carnivalesque as "[p]eople who are normally kept separate by social and spatial distance can accidentally meet" (243). The first Herlanders met by the men are three young women in a treetop (Herland 1915: 14-5). The men's climbing the tree with great difficulty to speak with them becomes a feminist reformulation of the 'encounter chronotope.' This chronotope is gendered in this way to reverse the lower position that women occupy in patriarchy. In other words, placing the women characters in a superior position, at the top of the tree, implies an explicit critique of the hierarchy '(hu)man/gender.' This scene is the first of a series of role-reversals, all of which place woman in the subject position. The visitors' courteous greeting-"doff[ing their] hats" (15)-is ridiculed by the Herlanders' laughter in response. Gilman seemed to be playing the role of the 'fool' (novelist), who has the right to mock (gender) norms of behaviour. Bakhtin agreed that "one of the most basic tasks for the novel [is] the laying-bare of any sort of conventionality, ... of all that is ... falsely stereotyped in human relationships" (1937-8: 162).

A more symbolic reading of this scene reminds us of the Biblical tree of temptation. Terry tries to attract the Herlanders by taking "a necklace" out of a "box" and "swinging his bright temptation" before them (Herland 1915: 16). Bridget Bennet has compared the naked arm of Terry, who is "devilishly handsome," to the serpent of Eden (1998: 45). I would like to add that the armplus-necklace compound can represent his desire of the phallus or his prematurity, both sexual and cognitive, as he arrived there already "armed with a theory" (Herland 1915: 20). As we will continue to see, the desire of the phallus-the identity between signifier and signified-is continuously unsatisfied

\footnotetext{
${ }^{7}$ Bakhtin should have made a gender distinction as follows: when it is not a metaphor, the 'road' plays a crucial role in the novels written by men, since they are the ones who usually enjoy (social) mobility-hence the vitality of the 'road' in the Beat generation. Unsurprisingly, all the examples Bakhtin gave are from male writers' novels. Other fictional forms (the 'domestic novel,' the diary form) have been favoured by female writers. Interestingly enough, the male protagonists of Herland-Ourland are middle- and upper-class men, who, as part of their leisure, decide to search for adventures in the "Woman Land" (Herland 1915: 2).
} 
by Gilman's playing around with all classifications. The men's situation, "in the fork of a great limb" (15), is frankly unstable: Van "nearly lost [his] balance" (15), Terry "made his snatch [of Alima's arm], quite vainly, almost losing his position" and "with inconceivable rapidity, the three bright creatures were gone" (17). It appears that the Herlanders do not let themselves be trapped by phallocentric conceptions. Not even by the narrator, who calls them "women" for the first time on page 19. In this way, the Ourlanders-i.e. the three male characters represented and all of us readers-are required to pause and reflect upon the 'new' kind of 'women' the Herlanders stand for. As already advanced, the creation of Gilman's Herlanders was influenced by the debates on the New Women of the fin-de-siècle, a period that accordingly sheltered debates on the 'crisis' of masculinity (Heilmann: 2000). In Herland, the male visitors have to be educated by the older women before they are allowed to deal with the female protagonists, who are among the youngest. ${ }^{8}$ A 'good' first-wave feminist, Gilman believed in the power of education and training for the improvement of society. This educational process takes place in a comic feminist recreation of the 'castle chronotope.'

Bakhtin identified the origin of the 'castle chronotope' in the Gothic genre-a genre that has not been very kind toward women characters and readers. In the Gothic, "the castle is saturated through and through with [...] the time of the historical past [... and where] human relationships involv[e] dynastic primacy and the transfer of hereditary rights" (1937-8: 245-6)-saturations that are of course patriarchal. It seems Gilman enjoyed the Gothic, which she practised in short stories such as "The Yellow Wallpaper," "The Giant Wisteria," and "The Rocking Chair." As in other of her works, in this saga, Gilman's allusions to a past time form part of the parody, since she was more interested in the future (results). Once in Herland, the Ourlanders spend a total of "nine months" (Herland 1915: 58) amongst the older women, "six" of which they are confined

\footnotetext{
${ }^{8}$ The men's second encounter occurs with the middle-aged women, who appear to them "as cool as cucumbers" (Herland 1915: 21). The phallic overtones of the comparison indicate that the men are powerfully impressed by them. That might be why the narrator can only describe them in negative terms: "They were not young. They were not old. They were not ... beautiful. They were not ... ferocious...” (19). Gilman further parodied the three explorers' patriarchal assumptions, by which they imagined that in the new country all "the women [...] would be young [...] and [...] charming" (20). This was part of Gilman's criticism of ageism, hence also her female characters that are only able to develop their whole potential at an old age-"A Surplus Woman," "Three Thanksgivings," "Mrs. Hines’s Money,” “The Widow's Might.”
} 
in "a sort of castle" $(53,29)$. On the one hand, the male explorers appear suddenly in an all-women society, which has not had contact with the outside world for two thousand years, and which explains why the Herlanders take precautions. On the other, it could be argued that the training process or even the castle is a metaphor for the womb since it is expected that, when the three adventurers leave it, they are re-born as new men. I would argue that the Herlanders' project of beginning "a new kind of men" (Ourland 1916: 189)-e.g. interested in practising fatherhood-starts with the 'castle chronotope' of Herland and is culminated by the birth of Van and Ellador's "son" at the end of Ourland (193).

In order to explain why Van, Terry and Jeff end up in such "[a] [p]eculiar [i]mprisonment" (Herland 1915: 24), I need to elaborate upon their encounter with the middle-aged women, whom Terry tries to swindle by offering them imitation jewellery. The older women refuse the offer and, after a while, are approached violently by the visitors. Not to fight with the travellers, the Herlanders respond by applying "anesthesia" to them (23). Supporting my argument on the birth of the new men, the narrator describes his awakening from the drug as a true rebirth (24). In her fictional work, Gilman was especially keen to portray men who faint and (re)awaken at some point, as if she wanted to literally awaken her male readers (Smith 1989: 129). For example, "The Yellow Wallpaper" ends with a male character, John, who faints. Since readers are deprived of his awakening, numerous questions have been raised on a most disturbing open ending. In the present case, as Vandyck turns into a (very) dialogic man progressively throughout Herland-Ourland, one would like to think he is the John of "The Yellow Wallpaper" being reborn."

So that these Ourlanders could be thoroughly re-educated, Gilman made them undergo some kind of infantilization first. Thus, Terry wakes up complaining: "They have taken away all our clothes [...] We have been stripped and washed and put to bed like babies-by these highly civilized women" (Herland 1915: 24). His complaint suggests a new manifestation of the series of role reversals (re)placing women in the subject position. Other signs of the Ourlanders' masculinity are erased as well: the tunics in which they are dressed make them look "like a lot of neuters" (26) and their hats look "like those [... of] the prince in the fairy tale, lacking the plume"-a "plume" that seems to allude

${ }^{9}$ In a different reading, Minna Doskow (1999) has interpreted that the male protagonist of Moving the Mountain, Gilman's first utopian novel, is the antecedent of the Van of Herland. 
to the phallus. Through a gendered 'castle chronotope,' women characters do not lose their entities as subjects but duplicate them, although problematically, at the cost of disempowering the men. This is coherent with first-wave feminism's radical (re-)conversion of patriarchal hierarchies into 'subject/object,' 'women/men.' Gilman's humorist appropriation of this chronotope is further related to traditional fairy tales. New infantilizations and feminizations occur when the three male friends try to escape through the castle's window, by throwing out "rugs, robes, [and] towels," as if they were a group of Rapunzels (34). The parody is completed when they are found and brought back by the Herlanders, which once again situates the Ourlanders in an inferior position. It is only after this episode when the three men decide to co-operate with the women. Thereafter, they are treated like real guests, being invited to eat delicious food (27) and "free to study as [they wish], and [...] not left merely to wander in the garden for recreation but introduced to a great gymnasium" (30), a quote reminiscent of "The Yellow Wallpaper." In fact, the 'castle chronotope' of Herland could be a rewriting of that in Gilman's well-known story. Nevertheless, whereas the female protagonist of "Wallpaper" is kept totally isolated, these Ourlanders' training is carried out by means of conversation and relationships. In this way, the Ourlanders "were indeed to learn the [Herlanders'] language, and [...] to teach [their] own" (Herland 1915: 28). For this purpose, each man is assigned a mature woman as a tutor -Zava to Jeff, Moadine to Terry, and Somel to Van. Of the three men, only Terry does not enjoy either the educating process or Herland itself (98). Feminists are conscious that educating a person is extremely complicated, since patriarchy constantly tries to compulsorily 'educate' women in its own image. In Herland-Ourland, Gilman could be accused of trying to transform the male characters into new men without giving them either literal or metaphorical freedom. Therefore reflecting on/pausing for Gilman's castle chronotope leads us to challenge and even reject some of her radical first-wave feminist strategies, which seek to assimilate people to her project, not through dialogical dialogues, but through conversations oriented toward total conversion.

Above I have mentioned that Gilman despised masculinist genres based on the Story of Adventure and the Love Story. In fact, she believed that both of these narrative forms were structurally the same ("Masculine" 1911: 119). A feminist reading of Bakhtin amazingly proves his unintended agreement with Gilman, at least with respect to the Greek romance, whose "essence of ... adventure-time," Bakhtin said, is love too (1937-8: 89). In Gilman's opinion, the love story usually portrayed in literature "is the story of the pre-marital struggle. 
It is the Adventures of Him in Pursuit of Her [...] The 'love' of our stories is man's love of woman [... and] the stories stop at marriage" ("Masculine" 1911: 120). If for Bakhtin all types of idylls had in common a 'unity of time' and a 'unity of place' (1937-8: 225), Ellador and Van's travels around the world in the second part of the saga work literally to destroy this chronotope. Rereading Bakhtin, idylls take place in a "narrow and reduced idyllic little world" that suggests the pastoral (232), birds chirping and a total abandonment to inanity. We could say that Herland-Ourland destroys the myth of idyll, or of constant unchanging love, through the union of Van and Ellador, whose love "grew like a tree" (Herland 1915: 90). By inventing a new chronotope we could name of 'real(istic) love,' Gilman paused to reflect on the irony of the idyll chronotope. After the three Ourlanders fall in love with three of the women, the author intentionally problematized a courtship full of "pitfalls" (91) as "[t]here was no sex-feeling to appeal to, or practically none. Two thousand years' disuse had left very little of the instinct" (92), and "[t]here was no accepted standard of what was 'manly' and what was 'womanly.' " In the words of the narrator:

[A] young and inexperienced [Ourlandian girl ...] educated with a background of caveman tradition, a middle-ground of poetry and romance, and a foreground of unspoken hope and interest all centering upon the one Event; and who has, furthermore, absolutely no other hope or interest worthy of the name-why, it is a comparatively easy matter to sweep her off her feet with a dashing attack (93).

Through a gendering of the 'chronotope of idyll,' readers are to pause and look at it from woman's point-of-view. Throughout her life, Gilman criticized the patriarchal education of women that just turned them into dependants of men (emotionally, economically). Gilman also insisted that, for patriarchy, "love" and "combat" deploy the same language ("Masculine" 1911: 119)-like the final "dashing attack" in the quoted excerpt.

Already in Women and Economics (1898), Gilman denounced that women's lack of educational training to work outside the home obliged them to get married in order to survive (e.g. 89). ${ }^{10}$ In her opinion, if women were

\footnotetext{
${ }^{10}$ Gilman's most famous affirmation in this respect was: "W[om]e[n] are the only animal species in which the female depends on the male for food, the only animal species in which the sexual relation is also an economic relation" (1898: 5).
} 
independent, "[t]here w[ould] be needed neither bribe nor punishment to force women to true marriage" (91). Gilman even asserted that "the higher development of social life following the economic independence of women makes possible a higher sex-life than has ever yet been known" (143). One would like to think that Gilman was talking about a 'human sex-life' (or sexuality), developed by dialogic sexual subjects. The truth is that her saga has been read as trying to recover the "sexual innocence" so typical of classical utopian texts (Ferns 1998: 34). I partly agree with this reading though there is room for further interpretation. Elaine Showalter has explained that women writers' literature of the Feminine Period "represented a reaction to a male sexual force that $\operatorname{str}[\mathrm{i}] \mathrm{k}[\mathrm{es}]$ women ... as alien" (1988: 189) since, in that period, the only sexual force taken into account was the male. Gilman constantly denounced that women were kept ignorant of all the world's matters, especially sex (see Gilman: 1895). Terry's offensive comment that the Herlanders are "[s]exless, epicene, undeveloped neuters!" (Herland 1915: 142), actually "sound[s] like" the typical opinion about the 'real' Ourlandian women of 1915-6. In contrast, the Herlanders are shown as "women one had to love 'up' ... instead of down. They were not pets. They were not servants" (141). At the end of Ourland, Ellador becomes pregnant, which evidences her and Vandyck's development of the cited 'higher' (hetero)sexuality. This change is facilitated by the fact that Van "learn[s] to see things very differently [while] living with [her]" (Herland 1915: 135). Gilman promoted the sexes' (prior) self- and mutual knowledge in order to achieve such a (dialogic) 'sex-life.' Unfortunately though, quarrels and abuse might infect love stories as well and, therefore, Gilman had to deal with the 'chronotope of rape.'

Throughout the history of literary criticism, it appears that rape is prone to be read metaphorically as something else-T. S. Eliot's The Waste Land, W. B. Yeats's "Leda and the Swan." This could be one of the reasons why there is not any study of the 'chronotope of rape.' Of course, the underlying reason is that literary scholars have traditionally ignored gender as a tool of critical analysis. In Herland, contrary to what happens to Van and Ellador, Terry and Alima "quarreled and parted, re-met and re-parted" (90), for she "never gave an inch" (87), and he "was not used to real refusal" (93). After their wedding, Alima still resists yielding to Terry's authority and, given his patriarchal training, he tries to rape her or to commit what is now labelled 'marital rape.' There is no metaphorical frustrated rape here; Alima does not symbolize a country or a mythical struggler, she stands for herself-and perhaps (metonymically) for any woman who may suffer sexual abuse. Throughout her life, Gilman was concerned with giving literary shape to gender violence. In 1997, Catherine J. 
Golden and Denise D. Knight edited Gilman's detective novel Unpunished, written in 1929 but not published before. In their "Afterword" to the novel, they argued that Unpunished not only addresses sexual abuse but "domestic violence and battered women's syndrome long before the phrases were introduced in our vocabulary" (222). ${ }^{11}$ Gilman's treatment of such private affairs (i.e. rape) in the public realm (i.e. literature) advanced the slogan 'the personal is the political,' which became definitional of the Second Feminist Wave.

In Gilman's feminist rewriting of rape, Terry is not able to rape Alima because, being "exceptionally strong" (Herland 1915: 87), she is not the conventional feminine figure repeatedly portrayed in literature. Gilman employs a meta-literary reference to point this out: "Othello could not have extinguished Alima with a pillow, as if she were a mouse" (132). Immediately, the Herlanders go to Alima's aid and "it was only the work of a few moments to have him tied..." (132). After readers perceive the literalness of the attempt of marital rape, they attend to a carnivalesque call for women's solidarity at the scene's end. As the narrator reflects much later, "[Terry's] idea was some quarry he was pursuing, something to catch and conquer" (138). The ideology of this potential rapist corroborates Gilman's critique that, for patriarchal thought, love and war share the same semantic field. As for critics who have read Herland as rewriting male (con)quest romances, Georgia Johnston has written that, the first time the male characters enter Herland, the country is described as a female nude (1989: 58) - “its broad glistening bosom" (Herland 1915: 9). Also in this line, Aleta Cane has made the following comparison: "Just as Marlow seeks to penetrate the 'heart of darkness' so Terry believes he must penetrate Alima in order to make her his own" (1995: 36). Once again, Johnston's and Cane's insightful comments support Gilman's assertion that the 'Story of Adventure' and the 'Love Story' are structural siblings ("Masculine" 1911: 119). Nevertheless, in this case, it is the women who "master" the attacker and teach him an unforgettable lesson (Herland 1915: 142). Therefore, the creation and gendering of this chronotope manages both to save the victim and to constitute a community of (feminist) women readers because, as corresponds to a feminist novel, Terry is judged for his crime. As the narrator recalls, "[i]n a court in our country he would have

\footnotetext{
${ }^{11}$ As for the plot, marital rapist Wade Vaughn abuses her wife till she opts for suicide. Some time afterwards, the widower appears dead in strange circumstances and the person that might have caused his death remains unpunished. In this sense, both the tone and denounce of Unpunished are evocative of Susan Glaspell's Trifles (1920). Herland (1915) partly anticipates both these works.
} 
been held quite 'within his rights,' of course" (132) due to "the custom of marital indulgence" (138), according to which Ourlandian women have to submit to their husband's deeds/ill-treatment. But in Herland, a eutopian (i.e. ideally good) land for women, the potential rapist is condemned to leave the country (133). Therefore, the rape event constitutes a means to put into practice several feminist genre-oriented strategies, among them, the creation of a feminist uncanny.

Tzvetan Todorov has interpreted the Freudian uncanny as "realiz[ing ...] one of the conditions of the fantastic: the description of certain reactions, especially fear [... that is linked to] scenes of cruelty, delight in evil and murder" (1993: 478). In most fantastic works, the scared character (the object) is almost always female and the one causing fear or dissipating it (the subject) is male. Fortunately, Marleen S. Barr has theorized upon the feminist (re)readings of the patriarchal uncanny:

Shocked after encountering the victimized female protagonist (the patriarchal uncanny), feminist readers identify with her, hesitate, and wonder how she (and they themselves) will survive. The protagonist also hesitates (awakens), questions the patriarchal uncanny's control over her life story. She pauses to create a space in which to rewrite herself. In turn, 'the actual reader identifies [...] [herself] with the character' (Todorov, 33) and reads patriarchy negatively. This hesitation and negative reading open a new narrative space [...] so that it can encroach upon the territory of the patriarchal real (1992: 200-1, my italics).

Curiously enough, Barr's theorization on this 'space' is comparable to my argument on the dialogical 'pause' offered by the chronotope. Barr even uses the verb 'to pause,' an amazing coincidence, to refer to a space in which readers put into question the naturalization of uncanny scenes. I would add that the 'new narrative space' forms part of the 'chronotope of estrangement' characteristic of the utopian genre, which here is gendered. As Barr and myself, Gilman was convinced of the important part played by literature in the creation of the cultural imaginary ("Masculine" 1911: 117). Readers who are able to 'estrange ourselves' and 'not naturalize' uncanny scenes are expected to react negatively against sexist stereotypes and thus criticize patriarchal culture. The uncanny can be positively related to more questions affecting women, such as (the 'chronotope of) motherhood.' 
To explore the uncanny more deeply, I would like to revise Freud's essay on this matter. Freud began his study by considering the etymological origin of the German word unheimlich ("uncanny"), which comes from heimlich ("canny"), and which has several contradictory meanings: familiar, friendly, concealed, hidden from public sight, uncanny, strange, malicious (220-6). Then, Freud decided to elaborate upon a positive interpretation of unheimlich related to meaning 'not strange' (224-6). So it seems the uncanny is not something new or 'other' but something, which was familiar to our lives a long time ago, and which was later alienated from us through a process of repression (241). Finally, Freud turned to Schelling's definition by which the uncanny is something that, destined to be kept out of sight, has come to light. Going back to Herland's 'chronotope of rape,' a feminist uncanny reading of any text generates from the uncanny elements involved in it. In this case, a 'private' affair, sexual assault, is made 'public' both when the women of Herland defend the victim from being raped and when they judge the attacker. The exposure of rape and its rejection disconcerts the narrator, who says, "I do not recall a similar case in all history or fiction" (Herland 1915: 142). The politicization of the personal, following the 1970's slogan, helps women not only in their feminist goals but, primarily, in the maintenance of their psycho-physical integrity. Second, in Freud's essay, among the examples of the uncanny are female genitals (1925: 244) and the fantasy of living in the maternal womb $(243,248)$. In relation to this last example, motherhood is a central theme in Herland to the point that parthenogenesis is what has propitiated the existence of a women's country.

When Van, Jeff and Terry fly over Herland, they are amazed by its "civilized" appearance, for instance, its "well-built-roads" (Herland 1915: 11). When the only people the Ourlanders can see are female, their dialogue is as follows: “'Only women there-and children,' Jeff urged excitedly ... 'But they look-why, this is a civilized country!' [Van] protested. 'There must be men' ... 'Of course there are men,' said Terry. 'Come on, let's find 'em.' " Their reactions show conformity with a patriarchal system that associates men with Culture and women with Nature (Ortner: 1974). In Herland, Gilman invented a world in which (civilized/male) 'production' and (female) 'reproduction' are neither incompatible nor opposite but, on the contrary, can coexist and help one another. If motherhood opens Herland, both motherhood and fatherhood function as a connecting thread throughout the saga and lead to the parenthood that closes Ourland. Given the centrality of the subject and its (re)definition in a concrete time and space, we can talk of a 'chronotope of motherhood.' Needless to say that no such chronotope was ever studied by Bakhtin and we would need 
to peer into the history of literature to know how the 'chronotope of motherhood' has (or has not) been represented. As in the gendered chronotopes examined so far, the 'chronotope of motherhood' provides us with a dialogical pause to rethink mothers' activities.

I would like to argue that showing all these mothers in open, public spaces"r[u]n[ning] out of the houses" and "gather[ing] in from the fields" (Herland 1915: 11) - is a manifestation of the Freudian uncanny. That is, in patriarchy, the mother, who 'was familiar' to us, has been kept out of sight (in the private sphere) and, in Herland, the mother comes back to light. In the words of Rosemary Jackson the uncanny "uncovers what is hidden and, by doing so, effects a disturbing transformation of the familiar into the unfamiliar" (1991: 65). Dialogical feminists have also argued that, by defamiliarizing a concept (here 'mother') that forms part of the "existing literary and social norms [...] in addition occurs the formation of a new ideology, a plan of resistance against the conventions" (Bauer 1988: 161). The feminist uncanny of the "motherhood chronotope' lets readers see mothers differently-they work as educators of their children and perform several functions outside the home. In sum, Gilman's Herlanders work to socialize the mother, to make her a participant in the symbolic world.

Throughout the saga, Herlanders and Ourlanders discuss maternal questions through and through. Such (uncanny) discussions imply making public/bringing to light the mother herself. Therefore, we learn that not only the space of discussion, but the 'space' of motherhood itself is also public. In order to deal with its 'time,' I need to highlight the Herlandian distinction between "motherhood" and "maternity." Whereas the latter term alludes to the "bear[ing of] a child," the former is related with the "highest art" of "education" (Herland 1915: 82). That is, in Herland:

Each mother had her year of [the] glory [of maternity]; the time to love and learn, living closely with her child, nursing it proudly, often for two years or more [...] But after[wards ...] the mother was not so constantly in attendance [...] She was never far-off, however, and her attitude toward the co-mothers [the child's educators], whose proud child-service was direct and continuous, was lovely to see (103).

I agree with Ruth Levitas that Gilman had no faith in the wonders attributed to maternal instinct, i.e. that a woman can give birth to a child does not imply 
that she can bring her/him up all by herself. With the introduction of the comothers, Gilman was anticipating kindergartens or the existence of other caretakers that help mothers in children's upbringing. Another question is that, in Gilman's fiction, women characters usually find a way to solve their problems by themselves. In several of her works, women organize themselves to look after children among themselves or through the kindergartens they themselves runsee Gilman: Diantha 1910. Therein, Gilman has been accused of not advocating men's participation in childcare (Gough: 1995, Kessler: 1995, Levitas: 1990). On the contrary, Gilman advocated both sexes' co-operation in the care of children in her short stories-"Garden" 1909, "Housekeeper"1910-and did so too in Herland-Ourland. Then, the crucial question to be answered is, why did she decide to fictionalize a world of parthenogenetic women?

Gilman's writing on parthenogenesis could be intended as a rewriting of the Genesis (Gubar: 1983), in which woman would be the origin of life. As Gilman herself disclosed (Man-Made 1911: 3), her interest in parthenogenesis was encouraged by a work of Lester Ward, "[T]he Gynaecocentric Theory of Life." Gilman believed in parthenogenetic theory and repeatedly stated that the female was the 'race type' and the male, a 'variant' (see Man-Made 1911, Religion 1923, Women 1898). From a gynaecocentric point of view, in the beginning it was the female who helped the male to become "more human" (1898: 132). Gilman blamed the institution of patriarchy which, mainly through marriage, turned women (the primary producers) into mere consumers, whose "maternal energy" was appropriated by men (125-6). To do away with the "male (work)/female (domesticity)' hierarchy, Gilman created the parthenogenetic society of Herland, where daughters derive their identities exclusively from their mothers, and which supposes a challenge not only to religious but also to scientific texts-i.e. Freud's. Contrary to its traditional stereotype, motherhood is prolific even beyond (re)producing human beings. Practising the alliance between 'production' and 'reproduction,' the Herlanders had "developed all this close inter-service in the interests of their children. To do the best work they had to specialize, of course; the children needed spinners and weavers, farmers and gardeners, carpenters and masons, as well as mothers" (Herland 1915: 68). In her rewriting of the Western tradition, Gilman would revise history as well as literature in order to include women's deeds-spinning, weaving, farming, and so on-, of which we have almost no records (Reed: 1975). Only when we learn to acknowledge the mother 
as a (social) subject, Gilman would propose to then turn both mother and father into caretakers. ${ }^{12}$

One of the reasons why the Herlanders are happy with the men's visit is the possibility to move on from parthenogenesis to heterosexual reproduction. They believe such a move supposes an improvement, which turns them into what they curiously call "a bi-sexual race" (Herland 1915: 89, 119, 135; Ourland 1916: 63-4, 88). ${ }^{13}$ Playing on Nancy Chodorow's famous title, I will call the mentioned move 'the reproduction of heterosexuality.' Gilman was indeed a revolutionary feminist, but she was finally unable to envision a society where women could choose to have children without the need of consenting to heterosexual relationships. Apparently Gilman was more interested in criticizing her male contemporaries' lack of involvement in childcare. Creating a "dual parentage" (Herland 1915: 119) or a "New Motherhood' " (140) implied demanding fathers' full participation in child-rearing. As stated above, for the Herlanders maternity's time-space is limited and belongs to the biological mother. But motherhood's time-space can be occupied by other caretakers, so why not the father? A visionary as she was, here Gilman was foreseeing current discourse on shared parenthood-see note 12. That future place (chrono-tope) can be achieved, as Ellador contends, "[i]f we, in Herland, can begin a new kind of men!" (Ourland 1916: 189). That is, a land peopled by Celis, Jeff, Vandyck, Ellador, and their descendants would really be a both-Herland-and-Hisland, a 'chronotope of parenthood.' This leads me to again criticize that some people are purposefully excluded from Gilman's (parental) project. The Herlanders are interested in making what they think is "the best kind of people" (Herland 1915: 59) and, although repelled by the idea of abortion (70), they practise eugenics. Being parthenogenetic, they have managed to "breed out [...] the lowest types" (82). As Somel (tutor) explains, whenever there is a girl showing "bad qualities [...] we appea[1] to her [...] to renounce motherhood" (82). Consequently, in Herland child-rearing "is entrusted only to the most fit" (83). First-wave feminist

${ }^{12}$ Gilman's insight is useful to refine more recent writings on shared parenthood-e.g. Balbus: 1987, Chodorow: 1978, Markus: 1987. Instead of bringing fathers 'right away' into the traditional mother's terrain, Gilman warned us to 'first' re-place woman's image in our cultural imaginary. That is, unlike contemporary scholars, Gilman had little faith that woman's image could change in people's minds right after fathers started to care of their children.

13 The argument on this 'improvement' has to do with the evolutionary theories infecting Gilman's feminism-see Gabnocsik-Williams: 1998, Hausman: 1998, Magner: 1978, Peyser: 1998. 
Margaret Sanger also said: "more children from the fit, less from the unfit" (quoted by Kline, 2001: 2). Wendy Kline has connected Gilman's insistence on women's responsibility as makers of men with Theodore Roosevelt's and Edward E. Ross's preoccupation with (the white) "race suicide" and the fact that Roosevelt blamed the New Woman for not wanting to have children (10-1). No wonder, when Ellador arrives in Ourland she thinks that "such limited women [as most Ourlanders] cannot produce a nobler race" (Ourland 1916: 97). ${ }^{14}$ The most detestable side of Gilman's ideal(ized) motherhood lies in her rejection of the people that were not assimilable to her project-basically everyone who was not white, educated, heterosexual, middle-class and did not think according to Gilmanian feminism. Such a Eurocentric approach goes against the prodemocracy spirit of dialogics and must be definitely abandoned in the ongoing third feminist wave.

In With Her in Ourland (1916), readers experience a new 'chronotope of estrangement' through the eyes of Ellador, who is now Mrs. Jennings, while she and her husband (Van) travel around Ourland. Most importantly, readers are to think about the world from a woman's viewpoint, which genders the 'estrangement chronotope,' contributing enormously to Gilman's feminist project. Bakhtin wrote (and Gilman seemed to agree with it): "In the realm of culture, outsidedness is a most powerful fact in understanding. It is only in the eyes of another culture that foreign culture reveals itself fully and profoundly" (1970: 7). In Ourland, Mrs. Ellador Jennings is the foreigner that provides a comparative analysis and we (readers) are expected to 'estrange' ourselves through her eyes in order to see culture more 'fully and profoundly.' Readers are supposed to be as altered as Van, who "beg[i]n[s] to get a new perspective" (Ourland 1916: 87) as he is "[g]oing about with Ellador, among familiar conditions, and [as he is] seeing things [he] never dreamed were there" (159). ${ }^{15}$ It appears as if, besides Ellador, all feminists were 'foreigners' in patriarchy, since we need to disidentify ourselves from it so as to produce a feminist critique. And if genres are forms of thought/ways of seeing (Bakhtin 1934-5: 367), feminist schools or feminisms must be genres-see below. It must be accounted that Ellador's point of view is neither neutral nor the best, although Van comes to

\footnotetext{
${ }^{14}$ The saga employs the term "noble" and its derivatives to excess-(Herland 1915: 57, 68, 82, 90, 99; Ourland 1916: 64, 68, 72, 97, 102)-, something which is connected with Gilman's elitist preferences.

${ }^{15}$ These quotations evidence that, although Vandyck is the saga's narrator, the true focalizer is Ellador-for focalization, see Genette: 1990.
} 
believe in it blindly (Ourland 1916: 87). Actually, Mrs. Jennings' opinions are infected by xenophobia and other phobias, as any genre/any feminism might dangerously be. The couple's limited ways of seeing are perhaps most evident in during the trip to Asia, where Ellador blames Oriental women for foot binding (92-3) and Vandyck refers to "women in the East" as if they were all the same (101). Opinions like these have lead current critics to denounce the racial, ethnic and class-related prejudices of Gilman's "mixed legacy" (Knight 1999: 168)_ hence the works of Ceplair: 1999, Ganobcsik-Williams: 1998, Gilbert \& Gubar: 1999, Lane: 1979, Lanser: 1989, Newman: 1999, Peyser: 1998, and Stimpson: $1991 .{ }^{16}$

To attempt a conclusion to this article, I hope to have proved that only a 'different' reading of Bakhtin's chronotope works a useful tool to approach a feminist 'genre.' Therefore, I wish to suggest such 'different' usage of the chronotope so as to approach 'gender,' which is also chronotopic. In saying this I mean that gender is a relative concept depending on the chrono-tope (timespace) it occupies. Furthermore, we should consider at least two levels of analysis within it, so as to move from 'gender' to "genders"-a term coined by Brown: 1997. The usefulness of these two levels can be sketched out as follows: although in patriarchy women are subordinated by gender discrimination $\left(1^{\text {st }}\right.$ level of gender analysis), not all of them experience it in the same way $\left(2^{\text {nd }}\right.$ level). In the first feminist wave, Gilman referred to women as being all the same, providing a gender analysis of the $1^{\text {st }}$ level-e.g. 1898: 40-1. With contemporary feminists, I agree that the focus of critical theory should begin with 'gender' and then move to 'genders' since, usually, gender subordination is complicated by other factors. In other words, the study of $a$ woman must always be contextualized within the chronotope in which she lives. Such a chronotopic study of gender helps us to understand the differences amongst women according to race, class, ethnicity, sexual orientation, physical-mental (dis)abilities, religion, nationality, education, profession, political ideology, and family status, among others.

Throughout this article I have referred to the chronotope as a literary event that provides a 'pause,' an opening to reflection and creativity. Readers who read

\footnotetext{
${ }^{16}$ Apart from these opinions, Van and Ellador attempt to solve the problems of many Ourlanders-Blacks, immigrants, Jews, Native Americans, women-without actually talking to them. From what we have seen, Gilman's two-part novel is very rich in chronotopes (especially Herland). However, if read from Bakhtin's essay on "Discourse," the saga suffers from being quite monologic (especially Ourland). Those interested in the contrasts offered by a discursive analysis, see Núñez Puente 2006 (pp. 73-121).
} 
in different chronotopes can reaccentuate a situation/text or enrich it with new meanings. This is the kind of creative event that facilitates the dialogue among periods and also among cultures (Bakhtin 1937-8: 254). I have also introduced the idea of feminisms as Bakhtinian 'genres' or 'ways of seeing.' That is, since existence/vision is chrono-topic or dependent on time-space, each feminist current/feminism sees a part of the so-called woman's problem, or sees it differently, and all of them constitute a dialogical whole. Bakhtin referred to the heteroglossia of incorporated genres as a major characteristic of the novel (19345: 320). In the light of this, I suggest that we see and practice the feminist community as a dialogical novel, containing many different genres, in the form of consciously organized heteroglossia. My proposal calls for a not simple move from 'feminist dialogics'-the critical perspective deployed here-to a 'dialogical community of feminisms.' In such community/'genre,' a woman's voice should be able to reveal her (dis)content, let us say in a different 'style,' so as to be listened to and responded to effectively by her co-members. An example of this might help to clarify things. Unfortunately, already in 1995, in a conference on Gilman at the University of Liverpool, suggesting that Gilman might have been lesbian or bisexual "was sacrilege" (Bennett 1998: 50). This event must be taken as an instance of feminists who were not 'listening' to each other dialogically, or of the amount of learning still to be done by us in order to become dialogic enough.

Given Gilman's Eurocentric ideas, it would be unfair not to contextualize her thought in her own time and I have done so repeatedly. Moreover, a chronotopic reading of Herland-Ourland shows that Gilman dealt with many themes concerning women-sisterhood, professional work, heterosexuality, education, rape, the law, love, motherhood, and so on-in a literary and selfconscious manner. Gilman made use of the Herlanders, especially of Ellador, to 'speak up' for women. A true representative of the New Women, Ellador talks uninterruptedly while Van just listens patiently (Ourland 1916: 128-129, 134, 190). From a (Bakhtin-derived) 'discursive' point of view, Herland-Ourland can be qualified as poor in dialogics-see note 16. In spite of that, a (Bakhtin-derived) 'chronotopic' point of view on Gilman's saga offers a different interpretation. If, due to historical reasons, 1915-6 was first-world women's time to talk, it is now our time to listen. In the third feminist wave, we must acknowledge the chronotopicity of gender, and also move beyond it, in order to open the dialogue to more people. Dialogical feminists have finally rejected a feminism that ignores the existence of other oppressed peoples and encourage to open the dialogue to many more speakers-"Hispanics, lesbians and gay men, African and 
Native Americans, and other marginalized peoples" (Hohne \& Wussow 1994: xi). Taking into account all these other speaking subjects would surely lead to a radical restructuring of 'our lands.' All in all, through Gilman's proposals, feminists and non feminists can still 'pause' and learn that moving toward dialogue must definitively occupy our current chronotope.

\section{BIBLIOGRAPHICAL REFERENCES}

ANNAS, P. J., Rev. of Herland, Women's Studies, 4, 3, 1981, pp. 385-7.

BAKHTIN, M. M., The Dialogic Imagination. Four Essays, trans. Caryl Emerson \& Michael Holquist, Austin, U of Texas P, (1981) 2000.

BAKHTIN, M. M.., "Discourse in the Novel," (1934-5) Bakhtin 2000.

BAKHTIN, M. M., "Epic and the Novel," (1941) Bakhtin 2000.

BAKHTIN, M. M., "Forms of Time and of the Chronotope in the Novel. Notes toward a Historical Poetics," (1937-8) Bakhtin 2000.

BAKHTIN, M. M., "Response to a Question from the Nory Mir Editorial Staff," (1970) Speech Genres and other Late Essays, trans. Vern W. McGee, Austin, U of Texas P, (1986) 1999.

BALBUS, I. D., "Michel Foucault and the Power of Feminist Discourse," Benhabib \& Cornell, pp. 110-27.

BARR, M. S., Feminist Fabulation. Space/Postmodern Fiction, Iowa City, U of Iowa P, 1992.

BAUER, D. M., Feminist Dialogics. A Theory of Failed Community, New York, State of New York P, 1988.

BAUER, D. M. \& S. JARET MCKINSTRY, eds., Feminism, Bakhtin and the Dialogic, Albany, State U of New York P, 1991.

BENHABIB, S. \& D. CORNELL, eds., Feminism as Critique: on the Politics of Gender, Minneapolis, U of Minnesota, 1987.

BENNET, B., "Pockets of Resistance: Some Notes Towards an Exploration of Gender and Genre Boundaries in Herland," Gough \& Rudd, pp. 38-53.

BROWN, E. B., " 'What Has Happened Here.' The Politics of Difference in Women's History and Feminist Politics," The Second Wave. A Reader in Feminist Theory, ed. Linda Nicholson, New York, Routledge, 1997, pp. 288-99.

CANE, A., "Charlotte Perkins Gilman's Herland as a Feminist Response to Male Quest Romance," Jack London Journal, 2, 1995, pp. 25-38. 
CEPLAIR, L., "Introduction," Charlotte Perkins Gilman: A Non-fiction Reader, New York, Columbia UP, 1999, pp. 1-8.

CHODOROW, N., The Reproduction of Mothering. Psychoanalysis and the Sociology of Gender, Berkeley, U of California P, 1978.

CRANNY-FRANCIS, A., Feminist Fiction. Feminist Uses of Generic Fiction, Oxford, Polity, 1990.

DONALDSON, L. E., "The Eve of De-struction: Charlotte Perkins Gilman and the Feminist Recreation of Paradise," Women's Studies, 16, 1989, pp. 37387.

DOSKOW, M., "Introduction to Charlotte Perkins Gilman's Utopian Novels: Moving the Mountain, Herland, and With Her in Ourland," Gilman 1999, pp. 9-35.

FERNS, C., "Rewriting Male Myths: Herland and the Utopian Tradition," Gough \& Rudd, pp. 24-37.

FREUD, S., "Lo ominoso," (1925) Sigmund Freud. Obras Completas. Tomo XVII, trans. José L. Etcheverry, Buenos Aires, Amorrortu, (1976) 1988.

GABNOCSIK-WILLIAMS, L., "The Intellectualism of Charlotte Perkins Gilman. Evolutionary Perspectives on Race, Ethnicity, and Class," Gough \& Rudd, pp. 16-41.

GENETTE, G., Narrative Discourse Revisited, trans. Jane E. Lewin, Ithaca, Cornell UP, (1988) 1990.

GILBERT, S. M. \& S. S. GUBAR. “ 'Fecundate! Discriminate!' Charlotte Perkins Gilman and the Theologizing of Maternity," Charlotte Perkins Gilman. Optimist Reformer, eds. Jill Rudd \& Val Gough, Iowa City, Iowa UP, 1999, pp. 200-16.

GILMAN, C. PERKINS, From “Apropos of Literature," (1890) Knight 1997, pp. 104-5.

GILMAN, C. PERKINS, From "Coming Changes in Literature," (1915) Knight 1997, pp. 125-32.

GILMAN, C. PERKINS, What Diantha Did, (1910) Project Gutenberg: The Online Books Page. Comp. Christopher Hapka. Internet. 6-11-2001. $<$ http://ibiblio.org/gutenberg/etext02/ diant10.txt $>$.

GILMAN, C. PERKINS, “A Garden of Babies,” (1909) Kessler, pp. 129-36.

GILMAN, C. PERKINS, “The Giant Wistaria,” (1891) Gilman, pp. 1995.

GILMAN, C. PERKINS, Herland, (1915) New York, Pantheon, 1979. 
GILMAN, C. PERKINS., “Mrs. Hines’s Money,” (1913) Gilman 1995.

GILMAN, C. PERKINS, "Her Housekeeper,” (1910) Kessler, pp. 147-58.

GILMAN, C. PERKINS, The Living of Charlotte Perkins Gilman. An Autobiography by Charlotte Perkins Gilman, (1935) Wisconsin, The U of Wisconsin P, 1991.

GILMAN, C. PERKINS, The Man-Made World or, Our Androcentric Culture, (1911) New York, Charlton Co., 1971.

GILMAN, C. PERKINS, "Masculine Literature," (1911) Knight 1997, pp. 11624.

GILMAN, C. PERKINS, Moving the Mountain, (1911) Charlotte Perkins Gilman's Utopian Novels. Moving the Mountain, Herland and With Her in Ourland, Madison, Teaneck Fairleigh Dickinson UP, 1999.

GILMAN, C. PERKINS, With Her in Ourland. Sequel to Herland, (1916) Westport, Greenwood, 1997.

GILMAN, C. PERKINS, His Religion and Hers. A Study of the Faith of Our Fathers and the Work of Our Mothers, (1923) Westport, Hyperion, 1976.

GILMAN, C. PERKINS, “The Rocking-Chair,” (1893) Gilman 1995.

GILMAN, C. PERKINS, “A Summary of Purpose,” The Forerunner, 7, 2, Dec., 1916, pp. 286-90.

GILMAN, C. PERKINS, “A Surplus Woman,” (1916) Gilman 1995.

GILMAN, C. PERKINS, “Three Thanksgivings,” (1909) Gilman 1995.

GILMAN, C. PERKINS, “An Unnatural Mother,” (1895) Gilman 1995.

GILMAN, C. PERKINS, Unpunished, (1929) New York, The Feminist P, 1997.

GILMAN, C. PERKINS, “The Widow's Might,” (1911) Gilman 1995.

GILMAN, C. PERKINS, Women and Economics. A Study of the Economic Relation between Women and Men, (1898) New York, Prometheus, 1994.

GILMAN, C. PERKINS, "Why I Wrote 'The Yellow Wallpaper'," (1913) Golden, pp. 51-3.

GILMAN, C. PERKINS, "The Yellow Wallpaper," (1899) Golden, pp. 24-42.

GILMAN, C. PERKINS, "The Yellow Wall-paper" and Other Stories, Oxford, OUP, 1995.

GLASPELL, S., Trifles, (1920) The Heath Anthology of American Literature. Volume II, eds. Paul Lauter et al, Lexington, Heath \& Co., (1990) 1994, pp. 1169-79. 
GOLDEN, C. J., ed., The Captive Imagination. A Case Book on "The Yellow Wallpaper," New York, The Feminist P, 1992.

GOLDEN, C. J.\& D. D. KNIGHT, “Afterword,” Gilman 1997, pp. 213-33.

GOUGH, V., "Lesbians and Virgins: The New Motherhood in Herland," Anticipations. Essays on Early Science Fiction and its Precursors, ed. David Seed, Liverpool, Liverpool UP, 1995, pp. 195-211.

GOUGH, V.\& J. RUDD, eds., A Very Different Story. Studies on the Fiction of Charlotte Perkins Gilman, Liverpool, Liverpool UP, 1998.

GUBAR, S. S., "She in Herland: Feminism as Fantasy," Coordinates: Placing Science Fiction and Fantasy, eds. George E. Slusser et al, Carbondale, Southern Illinois P, 1983, pp. 139-49.

HAUSMAN, B. L., "Sex Before Gender: Charlotte Perkins Gilman and the Evolutionary Paradigm of Utopia," Feminist Studies, 24, 3, Fall, 1998, pp. 488-510.

HEILMANN, A., Nerw Woman Fiction. Women Writing First-Wave Feminism, London, MacMillan, 2000.

HERRMANN, ANNE, The Dialogic and Difference. An/Other Woman in Virginia Woolf and Christa Wolf, New York, Columbia UP, 1989.

HOHNE, K. \& H. WUSSOW, "Introduction," Hohne \&Wussow, pp. vii-xxiii.

HOHNE, K. \& H. WUSSOW, eds., A Dialogue of Voices. Feminist Literary Theory and Bakbtin, Minneapolis, U of Minnesota P, 1994.

HOWARD, J., Reading Gothic Fiction. A Bakbtinian Approach, Oxford, Clarendon, 1994.

HUMM, M., The Dictionary of Feminist Theory, London, Harvester Wheatsheaf, (1989) 1999.

JACKSON, R., Fantasy: The Literature of Subversion, London \& New York, Routledge, 1991.

JOHNSTON, G., "Three Men in Herland: Why They Enter the Text," Utopian Studies IV, eds. Lise Leibacher-Ouvrard \& Nicholas D. Smith, New York \& London, Lanham, 1989, pp. 55-9.

KESSLER, C. FARLEY, Charlotte Perkins Gilman. Her Progress toward Utopia with Selected Writings, Liverpool, Liverpool UP, 1995.

KLINE, W., Building a Better Race: Gender, Sexuality, and Eugenics from the Turn of the Century to the Baby Boom, Berkeley, U of California P, 2001. 
KNIGHT, D. D., "Charlotte Perkins Gilman and the Shadow of Racism," American Literary Realism, 32, 2, Winter, 1999, pp. 159-69.

KNIGHT, D. D., ed., Charlotte Perkins Gilman. A Study of the Short Fiction, New Mexico, U of New Mexico, 1997.

LANE, A. J., "Introduction," Gilman 1979, pp. v-xxiv.

LANSER, S. S., 'Feminist Criticism, 'The Yellow Wallpaper,' and the Politics of Color in America," Feminist Studies, 15, Fall, 1989, pp. 415-42.

LEVITAS, R., The Concept of Utopia, Syracuse, Syracuse UP, 1990.

LITTLE, J., The Experimental Self. Dialogic Subjectivity in Woolf, Pym, and Brooke-Rose, Carbondale \& Edwardsville, Southern Illinois UP, 1996.

MAGNER, L. N., "Women and Scientific Idiom: Textual Episodes from Wollstonecraft, Fuller, Gilman, and Firestone,” Signs, 4, 1, 1978, pp. 6180.

MARKUS, M., "Women, Success and Civil Society. Submission to or Subversion of the Achievement Principle," Benhabib \& Cornell, pp. 96109.

MEDVEDEV, P. N. \& M. M. BAKHTIN, The Formal Method in Literary Scholarship: A Critical Introduction to Sociological Poetics, trans. Albert J. Wehrle, Baltimore, Johns Hopkins UP, 1978.

MILLER, J. ELRIDGE, Rebel Women. Feminism, Modernism and the Edwardian Novel, London, Virago, 1994.

MORSON, G. S., "Bakhtin, Genres, and Temporality," New Literary History, 22, 4, 1991, pp. 1071-92.

MORSON, G. S.\& C. EMERSON, Mikhail Bakbtin. Creation of a Prosaics, Stanford, Stanford UP, (1990) 1997.

NEWMAN, L. M., White Women's Rights: The Racial Origins of Feminism in the United States, New York \& Oxford, OUP, 1999.

NÚÑEZ PUENTE, C., Feminism and Dialogics. Charlotte Perkins Gilman, Meridel Le Sueur, Mikhail M. Bakhtin, Valencia, Universitat de València, 2006.

ORTNER, S. B., "Is Female to Male as Nature Is to Culture?," Woman, Culture, and Society, eds. Michelle Zimbalist Rosaldo \& Louise Lamphere, Stanford, Stanford UP, 1974, pp. 67-88.

PEARCE, L., Reading Dialogics, London, Edward Arnold, 1994. 
PEYSER, T. GALT, Utopia and Cosmopolis. Globalization in the Era of American Literary Realism, Durham \& London, Duke UP, 1998.

REED, E., Woman's Evolution: from Matriarchal Clan to patriarchal Family, New York, Pathfinder, 1975.

RUSS, J., To Write Like a Woman. Essays in Feminism and Science, Bloomington \& Indianapolis, Indiana UP, 1995.

SHOWALTER, E., A Literature of their Own. British Women Novelists from Brontë to Woolf, London, Virago, 1988.

SMITH, M. A., "The Disoriented Male Narrator and Societal Conversion: Charlotte Perkins Gilman's Feminist Utopian Vision," American Transcendental Quarterly, 3, 1, March, 1989, pp. 123-33.

STIMPSON, C. R., "Feminisms and Utopia." Utopian Studies III, eds. Michael S. Cummings \& Nicholas D. Smith, New York \& London, Lanham, 1991, pp. 1-5.

TODOROV, T., The Fantastic. A Structural Approach to a Literary Genre, trans. Richard Howard, Ithaca \& New York, Cornell UP, (1970) 1993.

YAEGER, P., Honey-Mad Women. Emancipatory Strategies in Women's Writing, New York, Columbia UP, 1988.

Carolina Núñez Puente

cnunez@udc.es

Universidade da Coruña

Facultade de Filoloxía

Campus da Zapateira, s/n

15.071 A Coruña
Fecha de recepción: 27/07/2006

Fecha de aceptación:06/02/2007 